\title{
Western Interstate Water Compacts
}

\section{Howard R. Stinson*}

The negotiation and ratification of major compacts by the states involved and the subsequent consent by the United States include inherent problems of great similarity when the prime purpose of the compact is to arrive at an equitable apportionment of water among the states. These problems involve the interests of the states, persons, and other entities claiming through the states, and the interests of the federal government and those who now, or who may in the future, claim through the federal government.

The states' interests, generally catalogued, are (1) the protection of rights, obtained through state laws, to the consumptive or non-consumptive use of water, and (2) recognition of the privilege or right of the states to grant additional rights in the future with the assurance that, if within amounts recognized by subsisting compacts, they will be valid against the other states and the United States. The second presents a challenging legal problem to states that choose the compact route to settle their major differences in the water use field.

The interests of the United States, similarly catalogued, are (1) consumptive use rights asserted in the development of federal projects-principally reclamation projects, (2) the interests, stemming from the Constitution, ${ }^{1}$ that the United States has in navigable waters and tributaries of navigable waters, and (3) the interests of the United States in its water rights for use on "reserved" lands $m$ the sense that that term is employed in the case of FPC v. Oregon. ${ }^{2}$ There is also a fourth interest in the water for development of reserved Indian lands, whether reserved by treaty or executive order.

Interests within or among the individual water users and the states are very difficult to deal with effectively, especially so because conditions may change twenty-five or fifty years from the time a compact becomes effective. When the legislative and constitutional problems confronting the federal government are added, it is easy to see why a water law attorney, primarily interested in protecting an adequate supply of water for future irrigation of lands, can spend much of his time on these problems.

\#At the time of his recent demise, Mr. Stinson was a member of the Idaho Falls, Idaho, Bar; the Federal Legal Adviser on the Columbia Basin and Nevada-California Compacts; and Legal Adviser to State of Oregon on the Klamath River Compact with California. In addition, Mr. Stinson was formerly Federal Legal Adviser on the Republican River and Snake River Compacts and Federal Representative on the Belle Fourche River Compact.

1 U.S. Const. art. I, \& 8.

2349 U.S. 435 (1955). 
METHODS OF DEALING WITH THE PROBLEMS OF EQUITABLE APPORTIONMENT

There are two principal ways of dealing with the problems of equitable apportionment. One is by an original suit for equitable apportionment in the Supreme Court of the United States. ${ }^{3}$ The apportioning of waters without doubt presents a federal question when it arises in interstate streams. There are, however, some shortcomings to this first route. These were very well stated by Mr. Justice Roberts in the 1943 opinion with respect to Colorado v. Kansas. ${ }^{4} \mathrm{He}$ there stated, in denying the plea of Kansas for an apportionment of the waters involved: ${ }^{5}$

The reason for judicial caution in adjudicating the relative rights of States in such cases is that, while we have jurisdiction of such disputes, they involve the interests of quasi-sovereigns, present complicated and delicate questions, and, due to the possibility of future change of conditions, necessitate expert administration rather than judicial imposition of a hard and fast rule.

In all the cases read by this author the Court has shied away from dealing with future rights, except to the extent that the states may have stipulated about them. ${ }^{\mathrm{b}}$

The second nethod of dealing with the problems of equitable apportionment is the conpact route, a method now much favored, particularly when there are extensive interests in future uses of water, be they consumptive or non-consumptive. The route has the specific recognition of the Constitution, ${ }^{7}$ wherein it is provided that the states shall not make agreements among themselves without the consent of the Congress. It has the approval of the Supreme Court, as evidenced by the opinion in Colorado v. Kansas in which Mr. Justice Roberts said: ${ }^{8}$

Such controversies [concerning waters] may appropriately be composed by negotiation and agreement, pursuant to the compact clause of the federal Constitution. We say of this case, as the court has said of interstate differences of like nature, that such mutual accommodation and agreement should, if possible, be the medium of settlement, instead of invocation of our adjudicatory power.

Lastly, so far as the Administration has been able to speak through its

${ }^{3}$ See, e.g., Hinderlider v. La Plata River \& Cherry Creek Ditch Co., 304 U.S. 92 (1938); Hutchins, Selected Problems in the Law of Water Rights in the West 411 (1942).

4320 U.S. 383 (1943).

5 Id. at 392 .

${ }^{6}$ In FPC v. Oregon, 349 U.S. 435 (1955), when the Court spoke of rights being recognized, they included (though I doubt that the Court was aware of it) some measure of protection for future uses.

7 U.S. ConsT. art. I, \$ 10, cl. 3.

8320 U.S. at 392. 
Water Resources Policy Report of December 1955 by the Presidential Advisory Committee it has given its endorsement. It was there said: ${ }^{9}$

Such compacts must take into account the interests of each of the States involved as well as be compatible with the national interests and the Federal constitutional powers.

But more on the constitutional powers question later.

II

THE FEDERAL GOVERNMENT AND INTERSTATE COMPACTS

The states, in the belief that the federal government had severed land from water in the western states, have adopted the compact approach, having learned by forty or fifty or more years of experience that water problems are rarely settled among states by litigation. However, a person who wishes to make the point that compacts settle nothing cites the pending Arizona v. Califorria litigation, ${ }^{10}$ arising out of the Colorado River Compact, signed by six of seven commissioners on November 24, 1922 ${ }^{11}$-Arizona has subsequently signed. The author was fairly familiar with those problems in the mid-1930's, but can only speculate as to the issue, or the outcome now, and would not be so bold.

\section{A. Binding the Federal Government to the Terms of the Compact}

The states' belief concerning their control of non-navigable waters stems from the case of California Oregon Power Co. v. Beaver Portland Cement $\mathrm{Co}^{12}$ in which the Court stated that the Desert Land Act of $1877^{13}$ "effected a severance of all waters upon the public domain, not theretofore appropriated, from the land itself." And the states have advanced the argument that Congress by the acts of admission of those states whose constitutions include provisions claiming the ownership of water rights in the states themselves has approved this position. ${ }^{13}$

From these positions it was quite natural for the states, at least rehen dealing with non-navigable waters, to deal with the waters as coming under the jurisdiction of the various states involved. And that apparently is why,

9 Report by the Presidential Advisory Committee on Water Resources Policy, H.R. Doc. No. 315, 84th Cong., 2d Sess. 22 (1956).

10 Docket No. 10, Original, in the Supreme Court of the United States, October Term 1956.

11 U.S. DEP'T OF THE INTERIOR, DocUMENTS ON THE USE AND CONTROL OF THE WATERS OF InTERstate and Internationat Streasrs 39 (1956). The Colorado River Conipact was "approved" by the Congress by $\S 13$ (a) of the Boulder Canyon Project Act of December 21, 1928, 45 STAT. 1064, 43 U.S.C. § 617l (1952).

12295 U.S. 142, 158 (1935).

1319 STAT. 377, as amended, 43 U.S.C. \$\& 321-23 (1952).

14 This contention was advanced by some of the states in Nebraska v. Wyoming, 325 U.S. 589 (1945). 
in some early compacts on streams believed to be non-navigable, there was no attempt made to bind the United States in any manner, either by the states placing $\mathrm{n} ı$ the compact itself what the consent legislation should contain as minimal requirements, or by binding the Umited States by legislation enacted after the compacts were already consented to by the Congress. Examples of compacts that illustrate this kind of thinking are the La Plata River Compact of $1922^{15}$ and the South Platte River Compact of $1923^{10}$

The states have often dealt with the problen of binding the United States by legislation passed after the Congress had given its consent. Hownever in at least two cases that were handled in this fashion the rivers dealt with have been declared by act of Congress to be navigable.

There are provisions in both the Boulder Canyon Project Act of December 21, 1928, ${ }^{17}$ and the Act of April 11, 1956, authorizing the Colorado River Storage Project, ${ }^{18}$ making the Colorado River Compact and the Upper Colorado River Compact binding on the United States.

The denouement for the states came when the first Republican River Compact was vetoed. As the President said in his veto message of April 2, $1942: 18$ "It is unfortunate that the compact also seeks to withdraw the jurisdiction of the United States over the waters of the Republican Basin for purposes of navigation...." But the states would not be deterred; a year later a new compact was drafted, ratified, and consented to by Congress. ${ }^{20}$

Whether the Republican River was navigable of itself is beside the point. It is a tributary of a navigable stream. Hence there was a major federal interest. The first approach was that of declaring the river nonnavigable. Even if this had succeeded, if the river subsequently had been determined to be a tributary of a navigable stream, the effort would have been in vain under the authority of United States v. Rio Grande Dam and Irrigation $\mathrm{Co.}^{21}$

The negotiators for the states interested in the Republican River Compact, with considerable help from the federal representative and his legal

15 The text of the La Plata Compact is set forth in the Act of January 29, 1925, c. 110, 43 Stat. 796, by which the Congress gave its "consent and approval," and it also is published in U.S. DEP'T OF THE INTERTOR, DOCUMENTS ON THE USE AND CONTROL OF THE WATERS OF INTERSTATE AND Internationat Streams 88 (1956).

16 The text of the South Platte Compact is set forth in the Act of March 8, 1926, c. 46, 44 Stat. 195, by which the Congress gave its "consent and approval," and it also is published

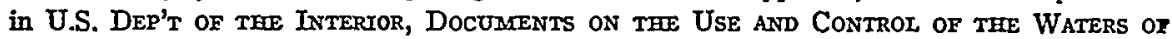
INTERSTate AND INTERAationat. Streams 210 (1956).

1745 STat. 1062, 43 U.S.C. \$ 617g (1952).

1870 Stat. 110, 43 U.S.C. $\$ 620 \mathrm{~m}$ (Supp. IV, 1957).

19 H.R. Doc. No. 690, 77th Cong., 2d Sess. (1942).

20 Act of May 26, 1943, c. 104, 57 STaT. 86. The text of the Republican River Compact also is published in U.S. DEP'T OF THE INTERIOR, DOCUNENTS ON THE USE AND CONTROL OF THE Waters of Interstate and Internationad Streams 140 (1956).

21174 U.S. 690 (1899). 
adviser, cast about for some means of overcoming the defect in the first compact so pointedly called to their attention in the veto message. At the same time they sought some legislative device for assuring that the federal consent legislation would, in the opinion of the state commissioners, meet the mimimum or basic points of the compact.

On the point of jurisdiction of the Umited States over the Republican River, the compact carried a specific provision recognizing the existence of federal jurisdiction. But it went on to provide that in the exercise of that jurisdiction the United States or those acting by or under its authority would recognize any established uses for domestic and irrigation purposes if the uses were within the terms of the compact and validly initiated under state law prior to the federal project which resulted in the impairment. The compact also had, as a basic point, a provision that any beneficial consumptive use by the United States or those acting under its authority should be taken into account in determining the amount of the allocation to each state.

The new compact, which was ratified and consented to, was approved by a reluctant President, who issued this statement in the course of his approval: ${ }^{22}$

... I believe it offers a sound solution to problems of water allocation and utilization on that stream. The procedure prescribed by the bill for the exercise of the powers of the Federal Government would not be entirely satisfactory in all circumstances but the prospects in fact for the exercise of such powers in the Republican basm are not great....

The Republican Basin presented only one or two facets of the bundle of federal interests above generally catalogued. It dealt with the problem of jurisdiction under the commerce clause in a maimer that, at the time and smce, seemed equitable; it required the United States, in the exercise of its superior jurisdiction, to take account of already established rights and to take counsel with the states before proceeding with a development based on superior federal jurisdiction.

The right of the United States to assert its superior jurisdiction by reason of the commerce clause, over navigable waters cannot be doubted ${ }^{23}$ and that it has plenary power to limit or qualify the use by its agencies of this power and authority is not to be doubted either because of the decision in Gerlach Live Stock Co. v. United States. ${ }^{24}$ The Gerlach case involved a situation in which the Congress had directed the Bureau of Reclamation to proceed under the Federal Reclamation Act of 1902, ${ }^{25}$ including section 8

22 U.S. DEP'T OF THE INTERTOR, DOCUNENTS ON THE USE AND CONTROL OF THE WATERS OB INTERSTATE ANd INTERNATIONAL StreaMs 148 (1956).

23 See United States v. Rio Grande Dam and Irrigation Co., 174 U.S. 690 (1899); United States v. Chandler-Dunbar Water Power Co., 229 U.S. 53 (1913); United States v. Appalachian Elec. Power Co., 311 U.S. 377 (1940).

24339 U.S. 725 (1950).

25 Act of June 17, 1902, c. 1093, 32 STAT. 388 (codified in scattered sections of 43 U.S.C. from $\$ 372$ through $\S 498$ ). 
thereof, ${ }^{26}$ on the matter of conformity to state law. The United States, through the Department of Justice, sought to avoid payment for water rights established under California state law. Mr. Justice Jackson, speaking for the Court, made this significant observation: "We cannot twist these words into an election on the part of Congress under its navigation power to take such water rights without compensation."27

There are to be compared with the Gerlach case these two cases: United States v. Twin City Power Co., ${ }^{28}$ and FPC v. Niagara Mohawk Power Corp..$^{29}$ The first case involved a condemnation of land owned by the power company; the land was to be used for the Clark Hill project on the Savannah River, a navigable stream. The Court there held, by a split decision, that Congress intended to exercise the full navigable servitude. The issue in the Niagara Mohawk case was whether the Federal Power Act ${ }^{30}$ was intended to abolish power rights established in a navigable stream. The Court held, by a split decision, that rights had been saved under section $27^{31}$ of the Federal Power Act.

It would be interesting to speculate on the extent of the permitted taking without compensation under the navigation servitude. Does it extend to projects in navigable reaches of a river but whose purpose is only indirectly to serve navigation, such as flood control? Does it extend to a project in like reach that is a single purpose project, such as power? These questions deserve much thought but it is not within the scope of this article to attempt to give definitive answers to them at this time.

\section{B. Problems Arising from FPC v. Oregon}

Another problem that is vexing the states arises out of the decision in $F P C$ v. Oregon, ${ }^{32}$ holding that private utilities can be licensed to undertake developments on what was assumed to be a non-navigable stream solely on the basis of the reserved status of the government lands on which the abutments of the dam were to rest.

How to deal with the multitude of federal interests in waters of an interstate stream? How to subject the United States to compacts-by making it a party, by its mere consent, by reliance on provisions of subsequent legislation, or by specific provisions relating to it in consent bills themselves?

The premise of this presentation is that the United States will not consent to being a party and thereby be bound by its provisions. Even if the

\footnotetext{
2843 U.S.C. $\$ \$ 372,383$ (1952).

27339 U.S. at 739.

28350 U.S. 222 (1956).

29347 U.S. 239 (1954).

3041 STAT. 1063 (1920) as amended, 16 U.S.C. $\$ \$ 791 a-825 r$ (1952).

3141 STAT. 1077 (1920), 16 U.S.C. $\$ 821$ (1952).

32349 U.S. 435 (1955).
} 
United States could and should be made a party to a compact, the question would then arise as to whether there was unequal yoking of parties, this because as a matter of constitutional law the United States could, by act of Congress, revoke its obligation at any time. The contract provision of the Constitution ${ }^{33}$ has a prohibition on impairment of obligation of contracts, but this prohibition acts against the states and not the United States. There is some protection under the Fifth Amendment, prohibiting the taking of property rights without due process. But the right to sue the Government on a contract is a privilege which can be removed by the Government without violating due process. However, aside from this ancillary problem, states who wish to compact are confronted with the dilemma of what course to pursue. Can they rely safely on a simple consent bill enacted by the Congress? Not in those cases which contain the usual recent form of denials that anything in the compact is binding on the United States, such as article XIX of the Upper Colorado River Basin Compact, consented to in 1949. ${ }^{34}$ It is noted in passing that it is a matter of speculation as to what will be the construction of the provisions of the Act of April 11, 1956, purporting to bind the United States to the terms of the compact. ${ }^{35}$

What of compacts in which these clauses of negation are absent? The provision of the Constitution bearing on compacts speaks in terms of states only. The text is as follows: 36 "No State shall, without the Consent of Congress ... enter into any agreement or compact with another State, or with a foreign power ...." There never has been a test of how far the United States can be bound if it becomes a signatory party or merely consents, but the suggestion may be made that the langnage of the Constitution is against that sort of construction. Therefore, it may be concluded that a compact, absent the usual negation clauses with respect to rights of the United States but which has been consented to by the Congress, would not be binding on the United States.

From the general cataloging of the interests of the states and the United States in a river basin, however, it is obvious that there should be some mutual accommodation, particularly if there is to be developed a long-range plan for the development of the water resources of the basin. The magnitude of the legal problem has recently been increased by the focusing of attention on rights of the United States to use the waters as it chooses on reserved lands under article IV, section 3, of the Constitution, which provides: "The Congress shall have Power to dispose of and make all needful

33 U.S. Const. art. I, $\$ 10$, cl. 1.

34 Act of April 6, 1949, c. 48, 63 STat. 31, 42. The text of the Upper Colorado River Compact also is published in U.S. DEP'T OF THE INIERTOR, DOCUMENTS ON THE USE AND CONTROL OF THE WATERS OF INTERSTATE AND INTERNATTONAL StrEaMs 218 (1956).

8570 STaT. 110, 43 U.S.C. $\$ 620 \mathrm{~m}$ (Supp. TV, 1957).

36 U.S. Const. art. I, §10, cl. 3. 
rules and regulations respecting the Territory or other property belonging to the United States ...."

These legal problems can and should be dealt with, in my opinion, in the manner indicated by, (1) the provisions of the Boulder Canyon Project Act of December 21, 1928, ${ }^{37}$ which purport to bind the United States, its permittees, licensees, and contractees and all users and appropriators of water stored, diverted, and carried or distributed by the reservoir, canals, and other works, to the terms of the Colorado River Compact, ${ }^{38}$ (2) the provisions that would be comparable to those adopted in the Republican River Compact, discussed above, or (3) an extension of the devices used in the Republican River Compact and the Belle Fourche River Compact ${ }^{30}$ to protect future uses of water as well as existing uses of water. The provisions that the compacting states believe to be basic or minimal would be specified in the compact itself.

\section{Indian Rights}

In all of this discussion there has been no specific allusion to Indian rights nor is it intended to nuake a suggestion about them, because each basin presents its own problems in this respect. Usually, the United States has insisted on a blanket exemption in the compact for all rights subsisting in individual Indians, bands, or tribes of Indians. But as water becomes more scarce and irrigable lands more valuable, it seems clear that the time will come when these blanket exemptions of Indian rights will be replaced by specific allocations to cover future developments for Indians.

III

THE COLUMBIA BASIN AND KLAMATH RIVER COMPACTS

The relationship between non-consumptive and consumptive use rights varies from basin to basin. There is now pending a proposed compact for the Columbia River Basin, which is built around the principle, among others, of subordination of non-consumptive use rights downstream in the lower two states or on the line that separates a lower state from an upper state, to the existing and future consumptive use rights in the upper stream area which lies east of the summit of the Cascades. The two lower states in this negotiation are Oregon and Washington and the two principal upper states are Idaho and Montana. This principle may be illustrated by reviewing a map of the Columbia River Basin. This will make plain how rapidly

3745 StaT. 1062, 43 U.S.C. §617g (1952).

38 Note 11 supra.

39 Act of February 26, 1944, c. 64, 58 STAT. 94. The text of the Belle Fourche Compact also is published in U.S. DEP'T OF THE INTERIOR, DocunIENTS ON THE USE AND CONTROL OF TER WATERS OF INTERStaTe aNd INTERNATIONAL Streans 14 (1956). 
public and private power developments have gone forward in the past two decades, particularly in the downstream states. There is more than enough water for the irrigation of upwards of one-and-one-half million acres capable of irrigation in Idaho alone; the problem is how to save this water for land. This figure represents the arable but now dry land that is capable of being developed under irrigation.

In the proposed Columbia Basin Compact there are no quantitative allocations of water to states or to groups of states, but the predictions of water use developments of a consumptive nature have indicated that in the foreseeable future there will be about five per cent or less taken out by future consumptive uses, measured at Bonneville Dam. This figure does not take into account the consumptive uses that are already established under state law for the yet-to-be-completed Columbia Basm Project. That proposed compact, first signed in January 1955 in order to be presented to the 1955 state legislative sessions, was recently modified in December 1956.

That compact has some additional features, three of which deserve mention: (1) It would give to the proposed Interstate Compact Commission extensive powers to prepare plans and to review plans prepared by others for the development of water resources which require federal authorization or a federal license. (2) It would provide for a review of the water rights problem by the year 2000, which can be extended to the year 2050 only if all of the states agree. (3) There is, with respect to rights stemming from the federal government, a limitation on the amount of depletion that would be permitted, measured by reference to study of the average flows over a twenty-year period, and taking as ultimate depletions a projection into the future made in $1947 .^{40}$

Another compact that is now being negotiated and has been ratified by both of the interested states follows these same devices. On the principle of subordination of future non-consumptive uses downstream or even within the Upper Klamath River Basin, the Klamath River Compact follows the pattern of the Columbia Basin Compact. But there was no occasion for going further with respect to existing non-consumptive uses in the downstream area. The area is divided into two parts. The first part is that defined as the Upper Klamath Basim and the most northerly portion of it lies wholly or almost wholly within Oregon, but there are approximately 100,000 acres yet to be developed by irrigation in the closed basins of California. The sense of the condition tied to this development in California is that the return flows appearing as surface waters in the Upper Basin must be returned to the river above Keno or at least above Copco Lake. This condi-

40 H.R. Doc. No. 531, 81st Cong., 2d Sess., Vol. 1, Plate 10 (1950). The present draft of the compact has a ratchet clause that would permit increases in the amount of depletions, but not decreases. 
tion, among others, must be specifically agreed to by the United States. Among the other important conditions to be agreed to by the United States are that future non-consumptive uses throughout the basin and outside of the basin will be prohibited, and that consumptive uses, while being permitted throughout the basin, will be recognized on the condition that they do not exceed 340,000 acre-feet in any one calendar year.

It has also been proposed that a specific waiver by the United States of immunity from suit be added to the Klamath River Compact consent bill. This provision, however, is not included in the requirements for the effectiveness of the consent legislation.

In all of this discussion it should not be forgotten that a federal consent bill can be altered, amended, or repealed at any time, and that most of them specifically so provide. But to the author's knowledge no western water compact has been so dealt with by the Congress.

This paper could be extended indefinitely by discussions of the positions of the federal agencies, but this shall not be done. Let us rest with the knowledge that we have, in writing, formal approval of the Columbia Basin Compact by the White House staff. We do not, however, as yet have an approval in writing of the Klamath River consent bill, ${ }^{41}$ even though the Klamath River Compact has been ratified by the two states involved. The added factor of the waiver of immunity by the United States may give rise to some problems. But by reason of experiences of recent date on the Rio Grande Compact in an original suit in the Supreme Court, ${ }^{42}$ it has been urged on the negotiators of the Klamath Compact that it would be desirable to have the waiver of immunity in the consent bill. The states, however, are prepared to back away from this point if it becomes a "sticking point" with the federal agencies.

\section{CONCLUSION}

In spite of the many problems arising from the use of the compact process, especially with regard to dealing with the federal government, it would seem that "compacts" present a better means of settling the differences of the states as to equitable apportionment of water. The "original suit" route may have some advantages, but, even though the Court retains continuing jurisdiction over it, it ends in a hard and fast decree.

${ }^{11}$ Since this paper was delivered the White House staff has approved the draft of consent bill, but with the deletion of waiver-of-suit provisions. See S. 2431, 85th Cong., 1st Sess. (1957); H.R. 8465, 85th Cong., 1st Sess. (1957); H.R. 8472, 85th Cong., 1st Sess. (1957).

42 Texas v. New Mexico, 352 U. S. 991 (1957); cf. Corker, The Western Water Rights Settlement Bill of 1957, 45 CALIF. L. REv. 604 at note 99, where the author comments critically on the implications of this decision. 